\title{
MEASUREMENT SYSTEMS FOR THE ENERGY PRODUCED BY A PHOTOVOLTAIC SYSTEM AND CONSUMED BY A BUILDING IN THE LUBLIN SCIENCE AND TECHNOLOGY PARK
}

\author{
Arkadiusz Małek \\ University of Economics and Innovation in Lublin, Faculty of Transport and Computer Science, Lublin, Poland
}

Abstract. The article contains a description of systems for measuring the energy produced by the photovoltaic system and its consumption by a building. The photovoltaic system consists of two micro-installations supplying two parts of the Lublin Science and Technology Park. An internet platform for monitoring photovoltaic plant operation is presented. The power generated and the amount of electricity produced are assessed. Also, an innovative system for monitoring and analysing the consumption and production as well as the efficient use of electricity in individual parts of the building is described. Based on the measurements carried out, the production of energy exceeded its consumption in one part of the building.

Keywords: photovoltaic systems, energy measurement, energy management, smart devices

\section{SYSTEMY POMIARU ENERGII PRODUKOWANEJ PRZEZ SYSTEM FOTOWOLTAICZNY I POBIERANEJ PRZEZ BUDYNEK LUBELSKIEGO PARKU NAUKOWO-TECHNOLOGICZNEGO}

Streszczenie. W artykule zawarto opis innowacyjnych systemów do pomiaru energii produkowanej przez system fotowoltaiczny oraz pobieranej przez budynek. System fotowoltaiczny składa się z dwóch mikroinstalacji zasilajacych dwa segmenty Lubelskiego Parku Naukowo-Technologicznego. Przedstawiono platforme internetowa do monitoringu pracy systemu fotowoltaicznego. Dokonano oceny generowanej mocy oraz ilości produkowanej energii elektrycznej. Nastepnie opisano innowacyjny system do monitoringu, analizy zużycia i produkcji oraz efektywnego wykorzystywania energii elektrycznej w poszczególnych segmentach budynku.

Slowa kluczowe: system fotowoltaiczny, pomiar energii, zarządzanie energią, inteligentne urządzenia

\section{Introduction}

Subjects related to the design, construction and control of energy produced by photovoltaic systems are eagerly taken up by scientists from various scientific disciplines. This is due to the mechatronic nature of photovoltaic farms. They contain mechanical components and electronic control based on measured and processed signals. Photovoltaic systems are devices of the Internet of Things capable of communicating with each other and with the building they supply.

Photovoltaics is one of the main global trends related to obtaining energy from renewable energy sources (RES) [25]. It is an estimated billion dollar market as an alternative to obtaining energy from fossil sources [6]. It turns out that this trend can be combined with other trends, such as Electro mobility. Electric cars, charged with electricity produced by photovoltaic systems [27], become completely zero-emission vehicles [17]. In addition, the increasing number of electric vehicles in Poland [32] and in the world will need large amounts of electricity to charge them [19].

Photovoltaic systems may be divided into stationary and mobile ones. Stationary ones are usually mounted on the roofs of buildings or on the ground [21]. Special ground structures are often created for the production of electricity and shadow generation for parked vehicles - so-called carports [27]. Having a source of electricity next to a parked vehicle, means that it may be used to charge parked electric vehicles [26]. Photovoltaic systems are mounted on various types of vehicles. First, public transport buses began to be used because of the availability of a large area for the installation of photovoltaic panels [30]. Researchers studied the subject of the safety of mobile photovoltaic systems [28] and their productivity [13]. Flexible photovoltaic panels can also be mounted on various body parts of passenger vehicles [14].

A very important area of research and development of photovoltaic system components is material engineering, providing innovative materials for the construction of photovoltaic system and energy inverters. Currently, composite materials [15], metal nanofibers [23], polymers [29] and perovskites [22] are used for the construction of panels. Modern materials are characterized by increasing efficiency, lower price and greater durability to weather conditions which may lead to degradation in photovoltaic system performance [18]. Therefore, these mechanisms should be thoroughly understood in order to effectively counteract them [3].
One of the very popular and useful areas for researching photovoltaic systems is their diagnostics. Intelligent algorithms allow quick and precise detection of irregularities in the operation of a photovoltaic system [10,24].

In order to effectively control the photovoltaic system itself and the use of produced energy, it is necessary to make precise measurements with a high degree of accuracy. Scientists are still working on the evaluation of mathematical methods characterizing the electrical parameters of photovoltaic panels [2]. The relationships between electrical parameters characterizing the photovoltaic system are very important [7]. Measurements are also very important in managing the energy produced and its use for charging energy storage batteries [1]. The measured parameters are processed and used to optimize the system operation. Developed control algorithms should thoroughly be validated in real conditions [31]. Modern photovoltaic inverters and energy management systems are increasingly advanced and have innovative functions related to the detection of the amount of dirt on panels and the generation of messages about the need to clean them [20]. Short circuits in the installation are also automatically detected and precisely located [5]. Many systems have the ability to monitor the parameters of each panel using individual optimizers [9, 11, 27].

The construction of a photovoltaic installation is widely recognized as a way of becoming independent of the energy produced by Energetic Groups. Every investor, be it an individual or an institution, is looking for the possibility of obtaining a return on the funds invested in the photovoltaic systems in the shortest possible time. By definition, this approach must involve the total or maximum use of energy produced for own needs. Any other eventuality associated with the sale of surplus energy extends the return on investment time. This is due to the manner in which electricity distributors and sellers account for electricity which is unfavourable for renewable energy producers [12]. Intelligent measuring systems are used to accurately measure the electricity produced by the photovoltaic system and the energy consumed by the building.

The Lubelskie Voivodship is located in one of the regions of Poland, considered to be optimal for the use of photovoltaic energy. The insolation is of course different in individual regions of the country and it ranges from $900 \mathrm{kWh} / \mathrm{m}^{2}$ to $1200 \mathrm{kWh} / \mathrm{m}^{2}$, which can be seen on the map prepared on the basis of the data of the Institute of Meteorology and Water Management (Figure 1). 


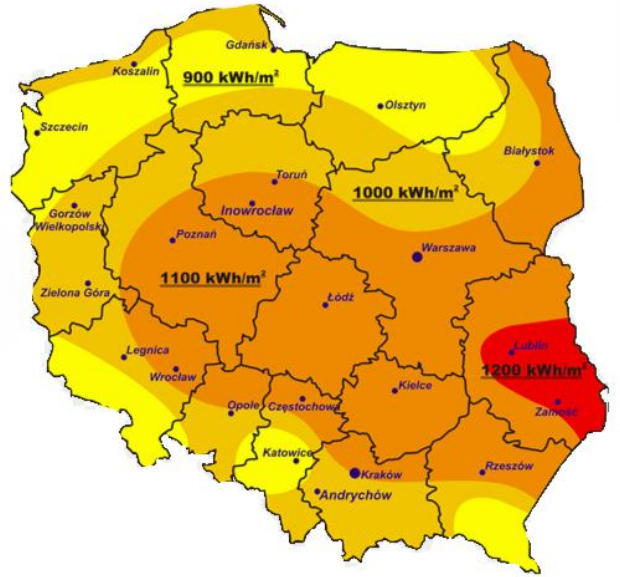

Fig. 1. Insolation in Poland [36]

Significant nationwide photovoltaic energy resources in the region are potentially an opportunity for the region to achieve the position of the national leader in the use of photovoltaic energy used both for heat production and electricity generation.

\section{Research object}

There is a ground photovoltaic system in front of the building of the Lublin Science and Technology Park (LSTP). These are 2 micro installations with a peak power output of up to $40 \mathrm{kWp}$ each using polycrystalline photovoltaic panels. The system was launched at the end of November 2018 and its appearance is shown in Figure 2. LSTP received funding from the Lublin Agency for Enterprise Support for the construction of the system. LSTP implemented the "Photovoltaic installation project on the ground next to the building of the Lublin Science and Technology Park" co-financed by the European Regional Development Fund under the Regional Operational Program of the Lublin Voivodship for 2014-2020, Priority Axis 4 "Environmentally friendly energy", Measure 4.2 "Energy production from renewable energy in enterprises. "The goal of the project is to increase the energy efficiency of the company by building a photovoltaic system in Lublin, next to the LSTP building as part of the project, 2 photovoltaic micro installations with a capacity of up to $40 \mathrm{kWp}$ were built. The project value is PLN 373,920.00, and the grant is PLN 135,324.99, which accounted for $45 \%$ of the eligible costs of PLN 300,500.00.

Both micro-installations were connected to two parts of the building and power various types of electric devices. The first micro-installation powers Section 4 of the building, in which most of the electricity supplies the servers of the Centre for Supervision over Eastern Poland Broadband Network. The second microinstallation supplies Section 5 of the building where the offices of the LSTP Board as well as offices and laboratories of tenants are located. The main consumers of electricity in this part are: lighting, air conditioning, office equipment and equipment of lowpower research laboratories.

General scheme of the electrical connection of the photovoltaic plant to the building of the Lublin Science and Technology Park is presented in Figure 3.

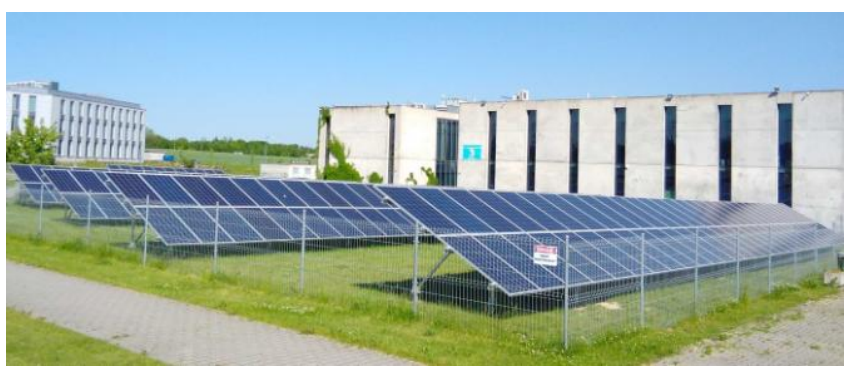

Fig. 2. Photovoltaic plant in front of the building of the Lublin Science and Technology Park [33]



Fig. 3. Scheme of the electrical connection of the photovoltaic plant to the building of the Lublin Science and Technology Park

The aim of the research is to use systems for measuring energy produced by the photovoltaic system and consumed by the LSTP building in order to energy management. In turn, the goal of energy management is the maximum use of electricity produced by the photovoltaic plant for own needs. This approach will allow for the fastest return on investment in the photovoltaic system.

\section{Measurement of energy produced by the photovoltaic system}

Almost all currently offered photovoltaic inverters have the function of measuring instantaneous power and the amount of produced energy. This measurement data can be transferred by wired or wireless transmission techniques to the server of the inverter manufacturer. After setting up the account and configuring it, the photovoltaic system administrator has access to the most important data related to the system operation [34]. Depending on the type of inverter, the volume of the data is extremely variable. They include a regular measurement of the system power (in $\mathrm{kW}$ ) or individual strings or even individual panels, which usually takes place every 15 or 20 minutes. In addition, the system records the amount of energy produced (in $\mathrm{kWh}$ ). Producer of the inverter wrote in User manual: "The display values may deviate from the actual values and must not be used for billing purposes. The inverter's measurement values are required for the operational control and to control the current to be fed into the electricity grid. The inverter does not have a calibrated meter".

Figure 4 presents the course of continuous power generated in total by 2 micro-installations $2 \times 40 \mathrm{kWp}$ on a sunny June day of 2019. It could be observed a very smooth increase in the generated power depending on the height of the sun above the horizon. The lack of large decreases and increases in the generated power means that the measurement concerned a completely cloudless day. The photovoltaic system with a total power output of $80 \mathrm{kWp}$ generated a maximum power of $68769.7 \mathrm{~W}$, which is $85.96 \%$ of peak power, which is measured in properly defined conditions.

Photovoltaic energy production on individual days of the month is shown in Figure 5. 


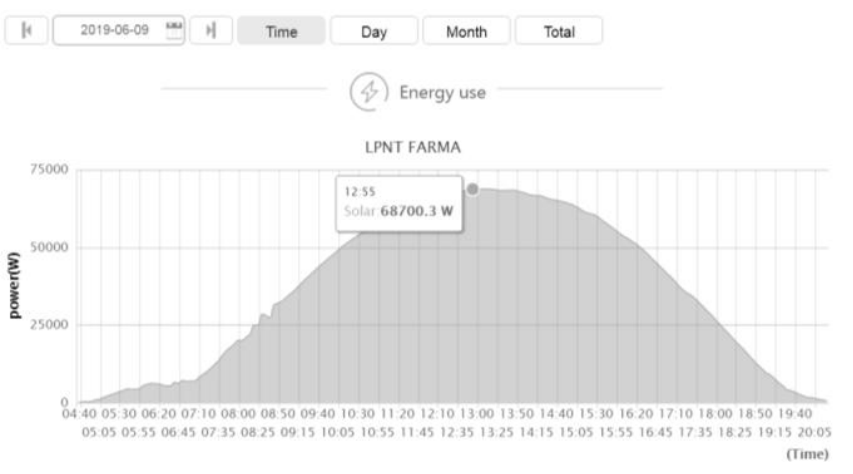

Fig. 4. Power generated by 2 micro-installations $2 x 40 \mathrm{kWp}$ (total) on June 9, 2019

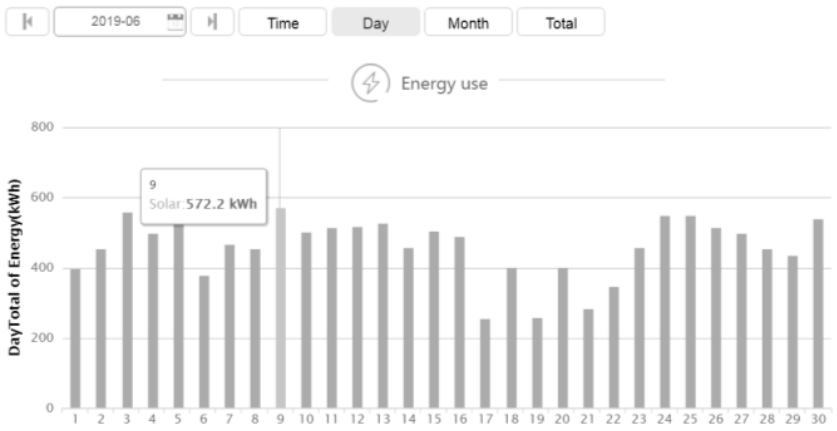

Fig. 5. Energy generated by 2 micro-installations $2 \times 40 \mathrm{kWp}$ on individual days of the month of June 2019

$2 \times 40 \mathrm{kWp}$ micro-installations have very similar instantaneous power generated, which provide into very similar amounts of energy produced. Data from the system can be considered separately for each of the micro-installations or for their sum (as in Figure 6). Measurement data can be exported at any time using the Export button visible in the diagram.

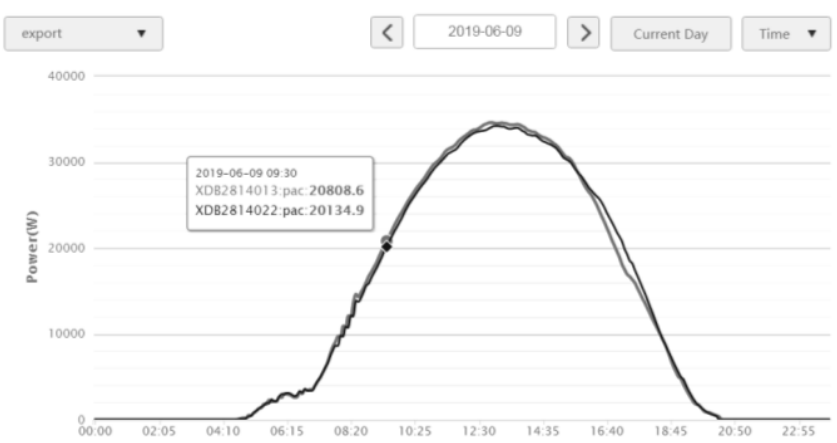

Fig. 6. Energy generated by 2 micro-installations $2 x 40 \mathrm{kWp}$ on June 9, 2019

\section{The requirement of the LSTP building for electricity}

The amount of energy drawn from the power grid and the surplus fed into it can be measured using a two-way electricity meter. Innovative measuring system was used to automatically obtain data from electricity meters installed in LSTP Sectors 4 and 5. The device is confirmation that innovative products have their origin and practical application in LSTP.

Used measuring system is an innovative system for monitoring, analysing consumption and production as well as the efficient use of electricity $[4,16,35]$. Its appearance is shown in Figure 7.

It consists of:

- A hardware - a small, battery-powered device that reads measured data from an energy meter.
- An application - an application for Android smartphones, used when synchronizing data from a device (via Bluetooth Low Energy) and as an online gateway.

- A Cloud - an internet platform on which readings preview, profiles, charts, reports, data export and API access are available.

The main advantages of measuring system are simplicity (installation takes place within a few minutes) and versatility. The system may be used by both home users as well as enterprises and companies seeking to optimize energy costs.

The device works with meters in both one- and three-phase electricity grid installations.

It is mounted on the optical port of the energy meter and obtains measurement data through the IEC 62056-21 protocol, making it compatible with many meter models of the largest manufacturers (Apator, Landis + Gyr, Iskra, Pozyton et al). The team has recently implemented the SML (Smart Meter Language) protocol used in meters in Germany and is working on adding meter support via the DLMS protocol. In this case the accuracy of measurement depends on other device - electricity meter. Metering accuracy of active/reactive energy is Class B (1.0)/2.0 respectively.

The measuring system Home version retrieves active energy consumption data and allows users to track costs, while the Business version also provides reactive energy data and allows users to adjust the ordered power. If measuring system is mounted on a bidirectional energy meter, the user also receives information about the energy fed into the energy grid, which is important for owners of photovoltaic systems.

The measuring system team is currently developing the second generation of the product called IoT based on LoRA, LTE-M and NB-IoT communication. The works are carried out with the technological support of Nordic Semiconductor. The project received a grant from the National Centre for Research and Development, which also includes intelligent algorithms and additional energy management tools.

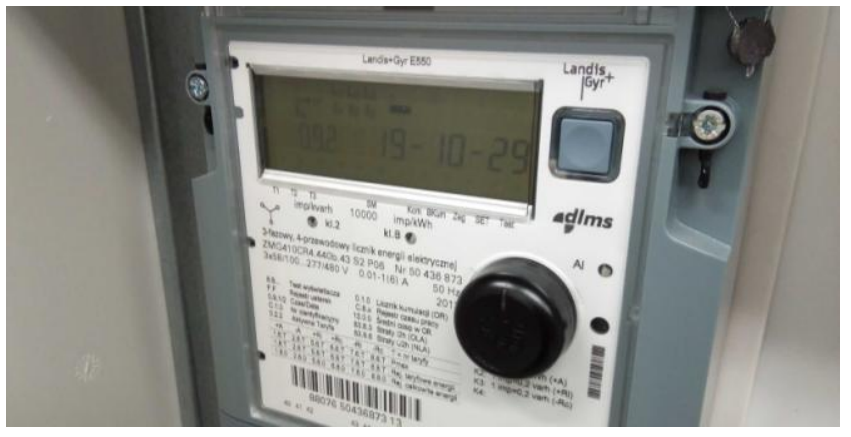

Fig. 7. Appearance of the measuring device

Two measuring system Business devices were purchased and installed. The measuring device, in the form of a beacon, works with bidirectional electricity meters on the LSTP Sectors 4 and 5. Then, via Bluetooth transmission, it transmits the measurement data obtained from the energy meter to the cloud. Data collected in the cloud can be displayed in the form of readable charts both on a PC and on a mobile device [3]. In June 2019, LSTP photovoltaic plant produced 13.8 MWh of electricity (data from Figure 8) and production from both installations was very close to the 50:50 ratio (according to Figure 6).

From the Sector 4 measurement data, it appears that almost all the energy produced by 1 micro-installation is used for the LSTP building's own requirements. The surplus produced and sold to the power grid was only $616 \mathrm{kWh}$ compared to consumption of almost $12 \mathrm{MWh}$. Almost total use of energy produced for own needs is a method for quick return of money invested in the photovoltaic system. 




Fig. 8. Graph of energy consumed (A+) and donated (A-) in Sector 4 LSTP in the month of June 2019

The situation in the Sector 5 of LSTP looks worse as shown in Figure 9. Compared to Segment 4, there is much lower daily energy consumption and a much larger surplus of energy produced. Predictions regarding the increase in energy consumption in Sector 5 during the summer did not come true. In the spring months from March to May, the building's management observed sporadic use of air conditioning by both LSTP administrative staff and tenants. A very warm June completely changed the situation and very frequent or continuous use of all available air conditioning during work was noted. This resulted in an increase in energy consumed by Sector 5 . But the increase was more than offset and the surplus of energy production in June increased compared to April and May.

The surplus of energy produced by enterprises is resold to an energy seller at a very unfavourable price constituting less than $25 \%$ of the total purchase price (including distribution and sale). This means a 4-fold increase in the payback time in the case of a large ratio of surplus energy sold to the distributor. To counteract this situation, the option of connecting other Sectors to Sector 5 should be considered. However, the situation is complicated by the ownership structure and the current design of the electrical network throughout the building.

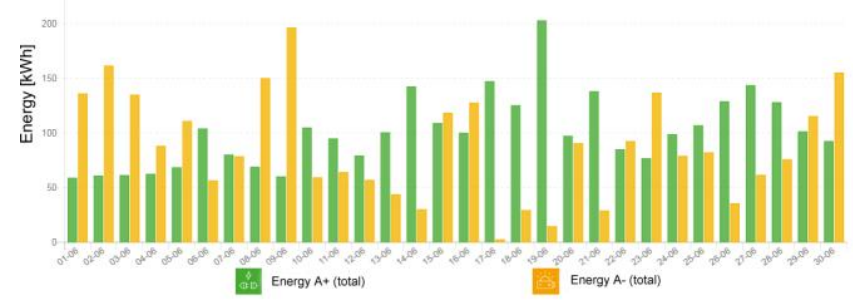

Fig. 9. Graph of energy consumed (A+) and donated (A-) in Sector 5 LSTP in the month of June 2019

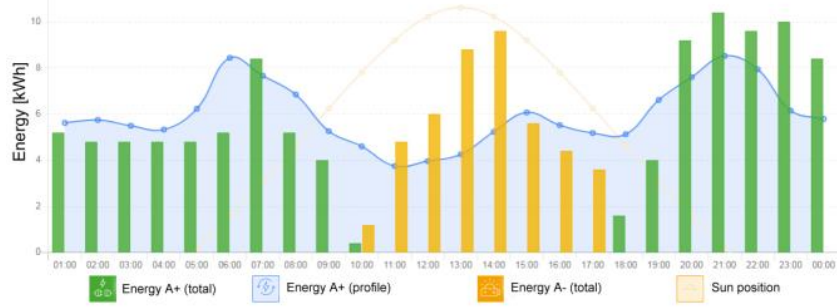

Fig. 10. Graph of energy consumed (A+) and donated (A-) in Sector 5 LSTP on a weekday-June 13, 2019

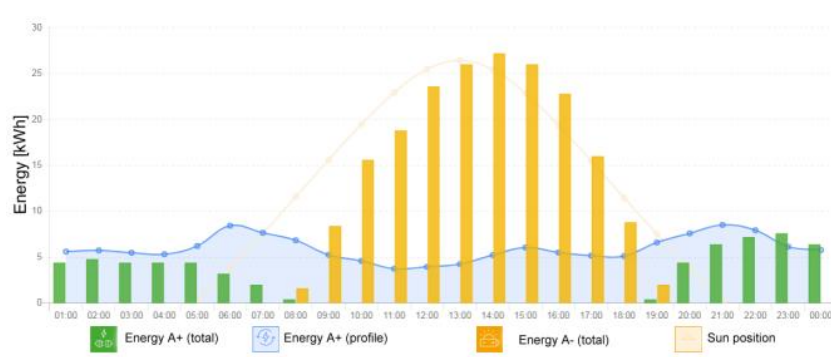

Fig. 11. Graph of energy consumed (A+) and donated (A-) in Sector 5 LSTP on a weekend day - June 9, 2019
The overview of consumption on weekdays (Figure 10) and on weekends (Figure 11) showed that the surplus of energy produced is much higher on non-working days.

The Cloud internet platform allows users to generate graphs of selected parameters, view meter readings and generate graphical reports from a selected period of time [4].

Standard charts allow users to track during the year, month, week, day (hour) and day (quarter hour):

- Active energy consumed (Energy A+),

- Energy given away (Energy A-),

- Reactive energy.

These data are raw data and carry a lot of useful information. They can clearly show when the preordered power is exceeded in a selected period. However, much more information can be obtained from reports that the online platform offers to generate automatically. Such an energy consumption report is divided into 3 parts, which correspond to the tabs on the platform:

1) Energy costs,

2) Energy consumption

3) Power consumption.

The graphs of consumption profiles in the Power consumption tab seem to be very interesting [1]. The graph in Figure 12 shows the profile of active power consumed during the day. The minimum, maximum and average values are presented in 15minute intervals. The profile clearly shows the night consumption values when the photovoltaic system is not working. During the day, the impact of energy produced by the micro-installation is visible, which during photovoltaic hours reduces the power consumed by Sector 5 to values close to zero. Maximum values occur on days of very low sunlight, when the power generated by the photovoltaic system is not able to cover the needs of Sector 4 . Therefore, the maximum values inform users about the potential power consumption of the building without a photovoltaic system.

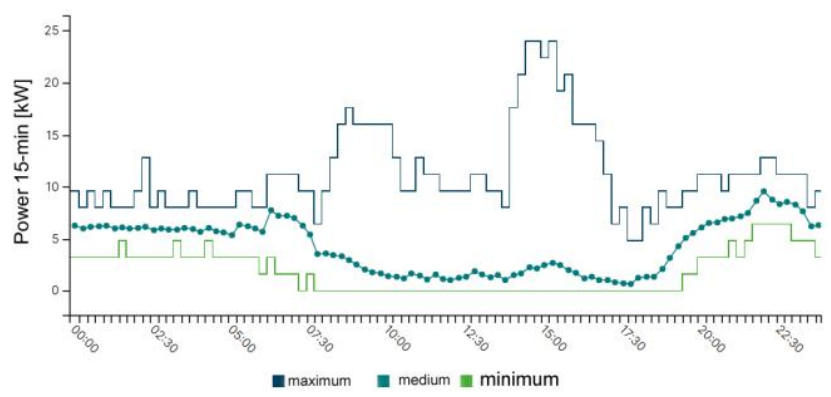

Fig. 12. 15-minute profile of active power consumed in Sector 5 LSTP in the month of June 2019

The average value is calculated from data from all days in the selected period of time, as shown in Figure 13. The graph shows a comparison of daily profiles of the active power consumed from the selected period. Users can learn from it how much the active power profiles tested differ for each day and detect anomalies. Importantly, users can take into account the average profile run on selected days of the week for the calculation.

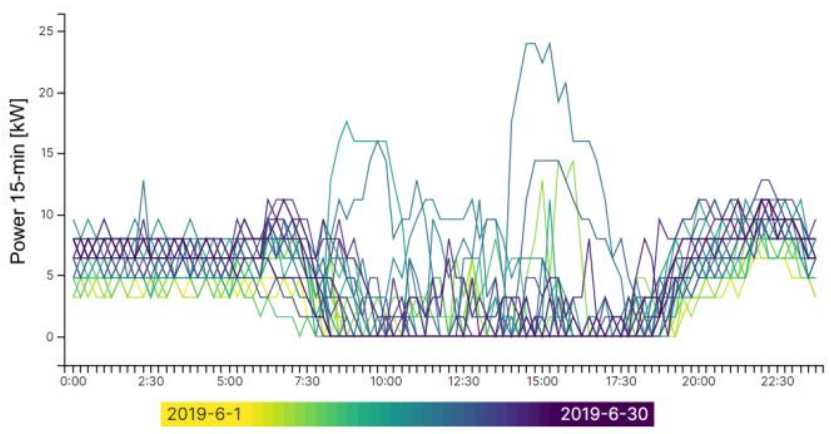

Fig. 13. Comparison of 15-minute profiles of active power consumed in Sector 5 LSTP in the month of June 2019 
This is the output of the producers of the measuring system to electricity consumers characterized by differentiated power consumption over various periods of time. Such extensive analysis capabilities allow users to detect certain relationships and use them in effective management of energy produced and consumed.

The graph in Figure 14 shows the trend of active power consumption in the selected range as in the example of a box graph. Using a given graph, it is possible to identify whether the active power consumption trend is symmetrical, how much data is grouped, and whether and how the power consumption trend is distorted.

Of course, the producers of the platform provide a detailed description of all values displayed in the form of a box chart for all interensted parties - see Figure 15

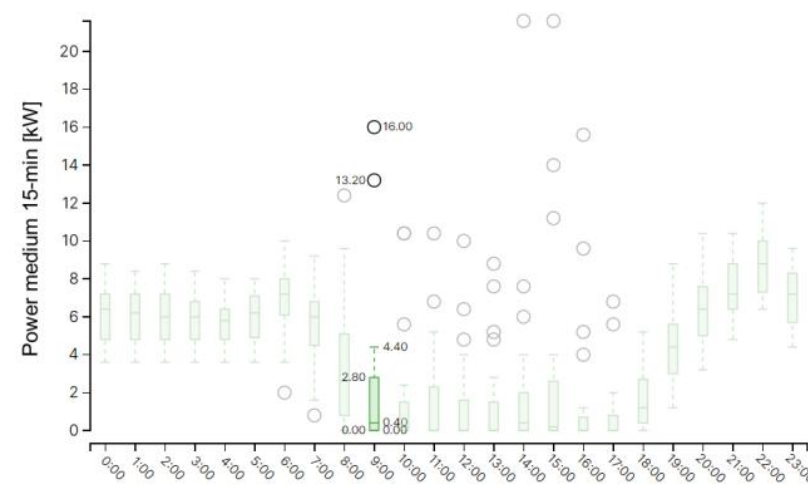

Fig. 14. 15-minute medium power - box chart in Sector 5 LSTP in the month of June 2019

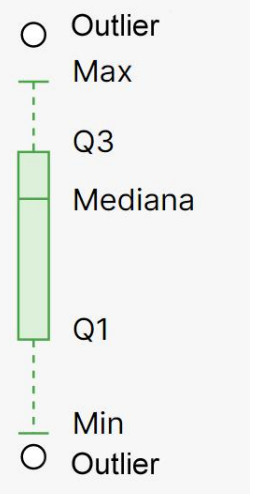

Fig. 15. Description of the values displayed on the box chart

The load duration curve, shown in Figure 16, describes the power consumption over the selected period. For example, a value of $1 \mathrm{~kW}$ for $10 \%$ means that for $10 \%$ of the period the power consumption was greater than or equal to $1 \mathrm{~kW}$. It can also be read for how long was exceed the preorder power.



Fig. 16. Load duration curve for active power in Sector 5 LSTP in the month of June 2019
Table 1 presents the values of energy consumed and given away to the power grid in various months of 2019. Sector 4 LSTP is characterized by high monthly electricity consumption. The amount of energy returned to the external grid is very small. This means that almost all the energy produced by the photovoltaic micro-installation is used for own needs. Sector 5 LSTP has a much lower monthly energy consumption than Sector 4. In addition, Sector 5 is not able to use all the energy produced by the photovoltaic system. In individual months, the surplus of electricity produced was found to range from 964.4 to $2622.4 \mathrm{kWh}$

Table 1. Active energy consumed and energy given away in various months of 2019 year in Sector 4 and 5 LSTP

\begin{tabular}{|c|c|c|c|c|}
\hline & \multicolumn{2}{|c|}{ Sector 4 } & \multicolumn{2}{c|}{ Sector 5 } \\
\hline $\begin{array}{c}\text { Month of } \\
2019\end{array}$ & $\begin{array}{c}\text { Energy } \\
\text { consumed } \\
{[\mathrm{kWh}]}\end{array}$ & $\begin{array}{c}\text { Energy } \\
\text { given away } \\
{[\mathrm{kWh}]}\end{array}$ & $\begin{array}{c}\text { Energy } \\
\text { consumed } \\
{[\mathrm{kWh}]}\end{array}$ & $\begin{array}{c}\text { Energy given } \\
\text { away } \\
{[\mathrm{kWh}]}\end{array}$ \\
\hline April & 12123.0 & 568.0 & 4043.0 & 1898.0 \\
\hline May & 12696.5 & 594.0 & 3305.6 & 2162.8 \\
\hline June & 11973.5 & 616.0 & 3038.4 & 2622.4 \\
\hline July & 12740.0 & 527.5 & 3682.4 & 1928.4 \\
\hline August & 14735.0 & 317.5 & 4848.8 & 1728.8 \\
\hline September & 13560.0 & 376.5 & 3680.8 & 1511.2 \\
\hline October & 15009.5 & 109.5 & 4330.4 & 964.4 \\
\hline
\end{tabular}

These are significant amounts of energy given away in Sector 5 that can significantly affect the payback time of an investment in a photovoltaic micro-installation. The author propose to use the excess energy produced to charge electric cars.

\section{Summary and conclusions}

A photovoltaic system consisting of two micro-installations with a power output of up to $40 \mathrm{kWp}$ each was built to supply electricity to two sectors of the Lublin Science and Technology Park. The manager of the photovoltaic system has set himself the goal of returning the money invested in its construction in the shortest period of the time. The way to achieve it is total or maximum use of energy produced for own needs. Any other eventuality associated with the sale of surplus energy extends the return on investment time. This is due to the method of business practices electricity distributors and sellers which are unfavourable for the RES energy producers. The presented online platform for monitoring photovoltaic system operation is a very useful tool for monitoring performance and diagnosing photovoltaic system operation. It was used to assess the power generated and the amount of electricity produced by the photovoltaic system. An innovative system for monitoring, analysing consumption and production as well as efficient use of electricity in individual building sectors produces very wide possibilities. With its help, a surplus of produced energy was found in one of the sectors.

Sector 4 LSTP is characterized by high monthly electricity consumption. The amount of energy returned to the external grid is very small. This means that almost all the energy produced by the photovoltaic micro-installation is used for own needs. Sector 5 LSTP has a much lower monthly energy consumption than Sector 4. In addition, Sector 5 is not able to use all the energy produced by the photovoltaic system. It was proposed that it should be used to charge electric vehicles.

\section{Bibliography}

[1] Al Essa M. J. M.: Home energy management of thermostatically controlled loads and photovoltaic-battery systems. Energy 176/2019, 742-752

[2] Aoun N., Bailek N.: Evaluation of mathematical methods to characterize the electrical parameters of photovoltaic modules. Energy Conversion and Management 193/2019, 25-38. 
[3] Azizi A., Logerais P. O., Omeiri A.: Impact of the aging of a photovoltaic module on the performance of a grid-connected system. Photovoltaic Energy 174/2018, 445-454.

[4] Bień A., Janicki A.: Simple and efficient profiling of electricity consumer. Wiadomości Elektrotechniczne 3/2019, 42-45 [DOI: 10.15199/74.2019.3.8].

[5] Bliss M., Betts T., Gottschalg R.: Interlaboratory comparison of short-circuit current versus irradiance linearity measurements of photovoltaic devices. Photovoltaic Energy 82/2019, 256-263.

[6] Choudhary P., Srivastava R. K.: Sustainability perspectives- a review for photovoltaic photovoltaic trends and growth opportunities. Journal of Cleaner Production 227/2019, 589-612.

[7] Cibira G.: Relations among photovoltaic cell electrical parameters. Applied Surface Science 461/2018, 102-107.

[8] Coria G., Penizzotto F., Pringles R.: Economic analysis of photovoltaic projects: The Argentinian renewable generation policy for residential sectors. Renewable Energy 133/2019, 1167-1177.

[9] Dubard J., Filtz J. R., Cassagne V., Legrain P.: Photovoltaic module performance measurements traceability: Uncertainties survey. Measurement $51 / 2014,451-456$

[10] Gallardo-Saavedra S., Hernández-Callejo L., Duque-Pérez O.: Quantitative failure rates and modes analysis in photovoltaic plants. Energy 183/2019, 825836.

[11] Gao Q., Zhang Y., Yu Y., Liu Z.: A direct current-voltage measurement method for smart photovoltaic modules with submodule level power optimizers. Photovoltaic Energy 167/2018, 52-60.

[12] Głuchy D.: The comparative analysis of the profitability of investments in the renewable energy source. Informatyka, Automatyka, Pomiary w Gospodarce i Ochronie Środowiska 4b/2012, 28-31.

[13] Grabowski, Ł.: The productivity of photovoltaic structures mounted on the roof of city bus. Logistyka 3/2014, 2114-2120.

[14] Hai Vu N., Pham T.-T., Shin S.: Flat concentrator photovoltaic system for automotive applications. Photovoltaic Energy 190/2019, 246-254

[15] Imbuluzqueta G., Yurrita N., Aizpurua J., Cano F. J., Zubillaga O.: Composite material with enhanced ultraviolet performance stability for photovoltaic modules. Photovoltaic Energy Materials and Photovoltaic Cells 200/2019, 109947.

[16] Janicki A.: Enhancing Electricity Meters with Smart Functionality Using Metering System with Optical Sensors. ALLSENSORS 2019.

[17] Judzińska-Kłodawska A.: Energy consumption in electric cars and environment impact. Autobusy: technika, eksploatacja, systemy transportowe 6/2014, $149-151$

[18] Katayama N., Osawa S., Matsumoto S., Nakano T., Sugiyama M.: Degradation and fault diagnosis of photovoltaic cells using impedance spectroscopy. Photovoltaic Energy Materials and Photovoltaic Cells 194/2019, 130-136.

[19] Krupa K., Kamiński J.: Impact analysis of electromobility development on Poland's electricity consumption. Rynek Energii 6/2017, 8-13.

[20] Lay-Ekuakille A., Ciaccioli A., Griffo G.: Effects of dust on photovoltaic measurements: A comparative study. Measurement 113/2018, 181-188.

[21] Lis P. Piesyk J.: Energy consumption and energy efficiency of buildings. Fizyka Budowli w Teorii i Praktyce 3/2016, 21-28.

[22] Liu G., Kong L., Yang W, Mao H.: Pressure engineering of photovoltaic perovskites. Materials Today 27/2019, 91-106.
[23] Liu J., Jia D., Gardner J. M., Johansson E. M. J., Zhang X.: Metal nanowire networks: Recent advances and challenges for new generation photovoltaics. Materials Today Energy 13/2019, 152-185.

[24] Lu X., Lin P., Cheng S.: Fault diagnosis for photovoltaic array based on convolutional neural network and electrical time series graph. Energy Conversion and Management 196/2019, 950-965.

[25] Łukaszewski, J.: Trzy trendy na 2019 rok, które zmienią filozofię produkcji, zarządzanie i zużycie energii. Napędy i Sterowanie 2/2019, 46-47.

[26] Małek A., Filipowicz I.: Charging the electric vehicle from the photovoltaic minicarport. AUTOBUSY-Technika, Eksploatacja, Systemy Transportowe 11/2018, 37-40 [DOI: 10.24136/atest.2018.343].

[27] Małek A., Kowalczyk D.: Photovoltaic carport for electric vehicle charging. Autobusy: technika, eksploatacja, systemy transportowe 11/2016, 93-97.

[28] Siadkowska K. Grabowski Ł.: Safety of using mobile photovoltaic installations. Logistyka 6/2014, 9476-9485.

[29] Tatsi E., Griffini G.: Polymeric materials for photon management in photovoltaics. Photovoltaic Energy Materials and Photovoltaic Cells 196/2019, 43-56.

[30] Wielgus J., Kasperek D., Małek A., Łusiak T.: Developed generations of electric buses produced by Ursus. Autobusy: technika, eksploatacja, systemy transportowe 11/2017, 20-25.

[31] Yin E., Li Q., Xuan Y.: Experimental optimization of operating conditions for concentrating photovoltaic-thermoelectric hybrid system. Journal of Power Sources 422/2019, 25-32.

[32] Zarajczyk K., Małek A., Kośko M.: Constructional and functional assumptions of a Ursus Elvi vehicle with an electric drive. Autobusy: technika, eksploatacja, systemy transportowe 6/2018, 309-313 [DOI: 10.24136/atest.2018.082]

[33] http://lpnt.pl/ (access 2019.07.09).

[34] http://server.growatt.com/login.do (access 2019.07.09).

[35] https://onemeter.com/pl/ [access 2019.07.09).

[36] http://renovi.pl/naslonecznienie-w-polsce/ (access 2019.10.02).

\section{Ph.D. Eng. Arkadiusz Malek}

e-mail: arkadiusz.malek@wsei.lublin.pl

Assistant professor at the Faculty of Transport and Computer Science at the University of Economics and Innovation in Lublin. Machine, tooling and vehicle designer. In his scientific work, he deals with the use of alternative fuels for vehicle propulsion (LPG, CNG, E85, H2). Designer of photovoltaic systems for charging electric vehicles. Coordinator of many research and development projects. He actively cooperates with companies to apply to national and $\mathrm{EU}$ projects for research and development in enterprises. A long-time employee of the Lublin Science and Technology Park.

ORCID ID: 0000-0001-7772-2755



